\title{
Feed intake and production parameters of lactating crossbred cows fed maize-based diets of stover, silage or quality protein silage
}

\author{
Efrem Gebrehawariat • Berhan Tamir • Azage Tegegne
}

Accepted: 13 June 2010 /Published online: 25 June 2010

(C) The Author(s) 2010. This article is published with open access at Springerlink.com

\begin{abstract}
Thirty-six Boran $\times$ Friesian dairy cows (392 \pm $12 \mathrm{~kg}$; mean $\pm \mathrm{SD}$ ) in early parity were used in a randomised complete block design. Cows were blocked by parity into three blocks of 12 animals and offered normal maize (NM) stover (T1), NM silage (T2) or quality protein maize (QPM) silage (T3) basal diets supplemented with a similar concentrate mix. Feed intake, body weight and condition changes and milk yield and composition were assessed. The daily intake of DM, OM, NDF and ADF for cows fed the NM stover-based diet was higher $(P<0.05)$ than for the cows fed the NM silage and QPM silage-based diets. However, the daily intake of DOM $(9.3 \mathrm{~kg})$ and $\mathrm{ME}(140.8 \mathrm{MJ})$ for cows on QPM silage-based diet was higher $(P<0.05)$ than for cows on NM stoverbased diet (8.4 kg and $124.2 \mathrm{MJ})$ and NM silage-based diet (7.9 kg and $119.1 \mathrm{MJ}$ ). Body weight of cows was affected $(P<0.05)$ by the diet, but diet had no effect $(P>0.05)$ on body condition score, milk yield and milk composition. The digestible organic matter in the NM stover-based diet $(724 \mathrm{~g} / \mathrm{kg} \mathrm{DM})$ was lower $(P<0.05)$ than that in the NM $(770 \mathrm{~g} / \mathrm{kg} \mathrm{DM})$ and QPM silage-based diet $(762 \mathrm{~g} / \mathrm{kg} \mathrm{DM})$. It was concluded that the performances of the cows on the NM silage and QPM silage diets were similar and were not superior to that of the NM stover-based diet.
\end{abstract}

E. Gebrehawariat

Faculty of Agriculture, Wellega University,

Nekemte, Ethiopia

B. Tamir $(\square)$

Faculty of Veterinary Medicine, Addis Ababa University, P.O. Box 34, Debre-Zeit, Ethiopia

e-mail: berhantamir@yahoo.com

A. Tegegne

International Livestock Research Institute,

Addis Ababa, Ethiopia
Keywords Body condition score $\cdot$ Body weight change . Feed intake Production parameter - Quality protein maize silage $\cdot$ Normal maize stover
Abbreviations
ADF Acid detergent fibre
CP Crude protein
DM Dry matter
DOM Digestible organic matter
NDF Neutral detergent fibre
NM Normal maize
QPM Quality protein maize

\section{Introduction}

The major constraint to cattle production in Ethiopia is nutrition. Cattle are predominantly fed on natural pastures and crop residues. However, due to rising human population, traditional grazing lands are widely being converted to croplands, forcing cattle to graze on marginal and overgrazed lands with poor quality forge (Kitaba and Tamir 2007).

Maize is a major source of food for millions of poor Africans. According to CIMMYT (2000), three systems of maize utilisation as food/feed can be envisaged. First, harvesting the crop at grain maturity and using the grain for human consumption while the stover is used as livestock feed - this is the most common use of maize in developing countries; second, harvesting the plant at the dent stage, marketing the ears for human consumption and using the greener forage as feed; third, harvesting the whole plant at the dent stage and using it as livestock feed. The two latter 
options require a system of conserving the relatively higher quality forages.

Conserved feeds such as silages are an integral part of dairy cattle diet in intensively managed peri-urban dairy farms, although the availability of maize silage to such dairy farms has not been well documented. In Ethiopia, a new variety of maize referred to as "Quality Protein Maize" (QPM) is being promoted for adoption by smallholder farmers to improve agricultural production and ensuring food security (CIMMYT 2000). It is generally believed that QPM is superior to normal maize (NM) variety in terms of nutrient content and animal performance. This study tested the hypothesis that feeding QPM silage-based diet would result in superior performance in lactating crossbred dairy cows. Results were compared with stover- and silage-based diets from the traditional NM variety.

\section{Materials and methods}

Study site and animals

The study was carried out at the International Livestock Research Institute (ILRI), Debre Zeit Research Station in Ethiopia. The station is located at $38^{\circ} 58^{\prime} \mathrm{E}$ and $8^{\circ} 44^{\prime} \mathrm{N}$ at an elevation of $1,850 \mathrm{~m}$ above sea level. The mean annual rainfall and temperature during the study were $860 \mathrm{~mm}$ and $18^{\circ} \mathrm{C}$, respectively. The minimum and maximum temperatures in the barn were $16^{\circ} \mathrm{C}$ and $29^{\circ} \mathrm{C}$ with a mean temperature of $23^{\circ} \mathrm{C}$.

Thirty-six crossbred Boran (Bos indicus) $\times$ Friesian $($ Bos taurus) cows (50-75\% Friesian) in early lactation and 1-3 parities were used. Mean initial body weight of the cows was $392 \pm 12 \mathrm{~kg}$ (mean $\pm \mathrm{SD}$ ). The cows were de-wormed against internal parasites and sprayed against ecto-parasites prior to the beginning of the experiment.

Feeds, treatments and experimental design

Two maize varieties viz., NM and QPM were grown at ILRI Debre Zeit Research Station. The maize varieties were harvested at the dent stage and ensiled with average DM contents of $29 \%$ for NM and $31 \%$ for QPM, respectively, with no additives used for ensiling. Also, the stover of the NM variety was collected and stored for later use. The silages and stover constituted the basal diets, which were supplemented with similar concentrate mix. Treatments consisted of feeding the NM stover-based diet $+8 \mathrm{~kg} /$ day concentrate mix (T1), NM silage-based diet $+8 \mathrm{~kg}$ /day concentrate mix (T2), and QPM silage-based diet $+8 \mathrm{~kg} /$ day concentrate mix (T3). The cows in T1 were supplemented with $440 \mathrm{~g} /$ day of maize grain to compensate for the grains present in the maize cobs of silages in the basal diets of $\mathrm{T} 2$ and $\mathrm{T} 3$. The diets were formulated to contain a $\mathrm{CP}$ content of $10 \%$ in order to meet the $\mathrm{CP}$ requirement of a lactating cow producing $11 \mathrm{~kg}$ of milk.

Cows were fed individually and had free access to clean drinking water and mineral licks. They were adapted to their respective diets for 4 weeks prior to the expected dates of calving and continued on the same diet after calving.

The basal feeds were offered ad libitum whereas concentrate supplements were offered daily in two equal meals at 0830 and 1400 hours in separate troughs. Orts were collected and weighed daily between 0800 and 0830 hours the next day, before offering fresh feeds. The amount of the basal diets offered was adjusted to maintain $5 \%$ orts during the feeding trial of 90 days. The experiment was conducted in randomised complete block design with three treatments. The cows were blocked by parity into three groups, and four animals from each parity group were randomly assigned to one of the three treatments making 12 animals per treatment.

Feed intake, body weight change and milk yield and composition

The daily feed intake on a DM basis was determined by the difference between feed offered and orts. Initial body weight of the cows was recorded on the first day of the experiment and thereafter the body weight and body condition score of cows were taken at 2-week intervals after overnight fasting. Body condition score of cows was recorded by visual observation and manual assessment to score the dairy cows on a 1 to 9 scale (where $1=$ emaciated, $9=$ fat) combining the procedures of Nicholson and Butterworth (1986) and Edmonton et al. (1989) developed for Zebu (B. indicus) breeds of cattle and Holstein dairy cows, respectively.

The daily body weight gain of each cow was calculated as the difference between the initial body weight and final body weight divided by number of experimental days. Efficiency of feed utilisation was determined by dividing the daily DMI by $4 \%$ FCM (fat corrected milk) yield of each animal (NRC 2001).

The cows were hand milked twice a day at 0600 and at 1600 hours, starting the 7th day post-calving. Fat corrected milk (4\% FCM) yield was calculated according to NRC (2001). Milk samples were collected on 30, 60 and 90 days of lactation for seven consecutive days for analysis.

Faeces collection

At the end of the feeding trial, five randomly selected cows from each treatment were used in a digestibility trial. Cows were adapted to carry faecal collection bags for 3 days, which was followed by total faeces collection for seven successive days. Total faeces was collected and weighed every morning before feeding and $5 \%$ of the faeces was sub-sampled, placed in airtight plastic bags and stored in a 
Table 1 Ingredient proportion (\%) of experimental diets (DM basis) of cows fed either NM stover, NM silage or QPM silage-based diets
$N M$ normal maize, $Q P M$ quality protein maize

\begin{tabular}{lccc}
\hline Ingredient proportion (\%) & \multicolumn{2}{l}{ Treatment } & \\
\cline { 2 - 4 } & NM stover-based diet & NM silage-based diet & QPM silage-based diet \\
\hline NM stover & 45.4 & 0.0 & 0.0 \\
NM silage & 0.0 & 41.3 & 0.0 \\
QPM silage & 0.0 & 00 & 42.4 \\
Ground maize grain & 2.85 & 0.0 & 0.0 \\
Wheat bran & 46.6 & 52.8 & 51.78 \\
Molasses & 3.22 & 3.68 & 3.61 \\
Bone meal & 1.28 & 1.48 & 1.46 \\
Salt & 0.65 & 0.74 & 0.75 \\
\hline
\end{tabular}

deep freezer at $-20^{\circ} \mathrm{C}$. On the last day of the collection period, samples were thawed and thoroughly mixed for each animal to determine DM, N, NDF and ADF. The same feeding levels were used as described in the feeding phase.

\section{Chemical analysis}

Feed and faecal samples were dried at $60^{\circ} \mathrm{C}$ for $48 \mathrm{~h}$ to constant weight in a forced draught oven and then ground to pass through $1 \mathrm{~mm}$ sieve. The DM, OM and ash in feed and faecal samples were analysed according to AOAC (1980) and NDF, ADF, ADL and ADF-ash according to Goering and Van Soest (1970). Metabolisable energy (ME, $\mathrm{MJ} / \mathrm{kg} \mathrm{DM}$ ) was estimated as $\mathrm{ME}=0.19 \times \mathrm{DOMD} \%$ (MAFF 1984), where DOMD is digestible OM in the DM.

Milk protein was analysed using formaldehyde titration $(6.38 \times N)$ as suggested by Scott (1986). The milk fat content was determined using the Gerber method with BS 696 and milk total solids with BS 1741 (British Standard Institute 1989). Lactose content of the milk was determined as the $[\mathrm{DM}-($ protein + fat + ash $)]$.

Data analysis

Data were analysed using the general linear model of the Statistical Analysis System (SAS 2002). Duncan's multiple range test was used to separate treatment means. The response variables were analysed using the statistical model: $Y_{i j k}=\mu+P_{i}+\alpha_{j}+\beta(x i j k-\bar{X})+.\epsilon_{i j k}$, where, $Y_{i j k}=$ dependent variable, $\mu=$ overall mean, $P_{i}=$ the $i$ th parity effect (block), $\alpha_{j}=$ the $j$ th treatment effect, $\beta=$ the true common slope of the regression line, $\bar{X} .=$ The overall mean of the covariate, $\epsilon_{i j k}=$ random effect. The initial milk yield was introduced into the model as a covariate.

\section{Results}

Ingredient proportion and chemical composition feeds

Ingredients used in the formulation of experimental diets for lactating cows are presented in Table 1. The treatment diets had similar ingredients, except the ground maize grain included in NM stover-based diet to compensate for maize grains present in NM and QPM silages. The mean chemical composition of the three maize varieties, concentrate mix and supplementary maize grain (Table 2) indicated that the CP content of the NM and QPM silages were similar and both were higher than the NM stover.

The NM and QPM silage-based diets had similar contents of DM, OM, NDF and ADF (Table 3). The DM content of the NM stover-based diet was higher than those of the NM and QPM silage-based diets. The NM stover-based diet had the
Table 2 Mean chemical composition of basal feeds, concentrate and maize grain used in feeding of lactating cows

$A D F$ acid detergent fibre, $A D L$ acid detergent lignin, $C P$ crude protein, $D M$ dry matter, $N D F$ neutral detergent fibre, $N M$ normal maize, $O M$ organic matter; $P$ phosphorus, $Q P M$ quality protein maize

\begin{tabular}{|c|c|c|c|c|c|}
\hline \multirow[t]{2}{*}{ Chemical composition } & \multicolumn{5}{|c|}{ Feeds used for the experiment } \\
\hline & NM stover & NM silage & QPM silage & Concentrate & Maize grain \\
\hline $\mathrm{DM}(\mathrm{g} / \mathrm{kg})$ & 918 & 882 & 881 & 879 & 884 \\
\hline $\mathrm{OM}(\mathrm{g} / \mathrm{kg} \mathrm{DM})$ & 875 & 914 & 919 & 921 & 980 \\
\hline Total ash (g/kg DM) & 125 & 91 & 81 & 6.5 & 2 \\
\hline $\mathrm{CP}(\mathrm{g} / \mathrm{kg} \mathrm{DM})$ & 52.3 & 76.6 & 73.6 & 147 & 93 \\
\hline NDF (g/kg DM) & 696 & 588 & 574 & 338 & 175 \\
\hline $\mathrm{ADF}(\mathrm{g} / \mathrm{kg} \mathrm{DM})$ & 462 & 366 & 371 & 120 & 61 \\
\hline ADL (g/kg DM) & 49 & 49.3 & 43.1 & 22.8 & 6.4 \\
\hline
\end{tabular}


Table 3 Nutrient composition of experimental diets (DM basis) of cows fed NM stover, or NM silage or QPM silage-based diets

$A D F$ acid detergent fibre, $A D L$ acid detergent lignin, $C P$ crude protein, $D M$ dry matter, $M E$ metabolizable energy, $M J$ mega joule, $N D F$ neutral detergent fibre, $N M$ normal maize, $O M$ organic matter, $Q P M$ quality protein maize

\begin{tabular}{lccc}
\hline Nutrient content & \multicolumn{2}{l}{ Treatment } & \\
\cline { 2 - 4 } & NM stover-based diet & NM silage-based diet & QPM silage-based diet \\
\hline DM (g/kg) & 897 & 880 & 880 \\
OM (g/kg DM) & 875 & 910 & 919 \\
DOM (g/kg DM) & 630 & 701 & 698 \\
Total ash (g/kg DM) & 125 & 90 & 81 \\
CP (g/kg DM) & 102 & 118 & 116 \\
NDF (g/kg DM) & 518 & 466 & 463 \\
ADF (g/kg DM) & 273 & 223 & 224 \\
ADL (g/kg DM) & 49 & 49 & 43 \\
ADF-ash & 44.6 & 33.7 & 38 \\
ME (MJ/kg DM) & 7.5 & 9.0 & 8.7 \\
\hline
\end{tabular}

lowest OM followed by the NM and QPM silage-based diets. The digestible organic matter (DOM) and ME contents in the NM silage and QPM silage-based diets were higher than the values in the NM stover-based diet, but they were similar among silage-based diets. The NM stover-based diet had higher NDF, ADF and ADF-ash than the silage-based diets, whereas the NDF and ADF in silage-based diets were similar. The NM silage-based diet had slightly higher ADFash than the QPM silage-based diet. Total ash was higher in $\mathrm{BM}$ stover than the two silages.

Nutrients intake and digestibility and production parameters

Mean DMI and OMI were higher $(P<0.01)$ for cows fed the NM stover-based diet than for the NM and QPM silagebased diets (Table 4). The daily crude protein intake was similar among dietary treatments. The DOM intake (DOMI) was higher $(P<0.05)$ for cows fed the QPM silage-based diet than cows fed NM silage-based diet, but the difference between the NM stover-based and NM silage-based diets was not significant $(P>0.05)$. The digestibility of DM, OM, $\mathrm{CP}$ and NDF was not affected $(P>0.05)$ by dietary treatments (Table 5).

The mean body weight loss of dairy cows during the trial was highest $(P<0.05)$ for cows fed the NM silage-based diet and lowest for cows fed NM stover-based diet (Table 4). There was no significant $(P>0.05)$ change in body condition score of the cows. Milk yield, 4\% FCM yield and milk composition of cows were not affected $(P>0.05)$ by dietary treatments (Table 6).

\section{Discussion}

Chemical composition of the feeds

The NM stover had low CP and high fibre fractions, characteristics consistent for most cereal crop residues. The
Table 4 Daily feed DM and nutrients intake, and body weight change and body condition score of cows fed NM stover, or NM silage or QPM silage-based diets

Means with different superscript letters in a row are significantly different at $P<0.05$

$A D F$ acid detergent fibre, $B C S$ body condition score, $B W$ body weight, $C P$ crude protein, $D M$ dry matter, $D O M$ digestible organic matter, $E F U$ efficiency of feed utilisation, $M E$ metabolizable energy, $N D F$ neutral detergent fibre, $N M$ normal maize, $O M$ organic matter, $Q P M$ quality protein maize, SEM standard error of means

\begin{tabular}{lcccc}
\hline & \multicolumn{2}{c}{ Treatment } & SEM \\
\cline { 2 - 4 } & NM stover-based diet & NM silage-based diet & QPM silage-based diet \\
\hline Intake & & & & \\
DM, kg/day & $12.6^{\mathrm{a}}$ & $11.1^{\mathrm{b}}$ & $11.3^{\mathrm{b}}$ & 0.25 \\
OM, kg/day & $11.4^{\mathrm{a}}$ & $10.3^{\mathrm{b}}$ & $10.5^{\mathrm{b}}$ & 0.22 \\
NDF, kg/day & $6.7^{\mathrm{a}}$ & $5.1^{\mathrm{b}}$ & $5.1^{\mathrm{b}}$ & 0.15 \\
ADF, kg/day & $4.3^{\mathrm{a}}$ & $3.3^{\mathrm{b}}$ & $3.4^{\mathrm{b}}$ & 0.12 \\
CP, kg/day & 1.28 & 1.31 & 1.31 & 0.017 \\
DOM (kg/day) & $8.4^{\mathrm{ab}}$ & $7.9^{\mathrm{b}}$ & $9.3^{\mathrm{a}}$ & 0.42 \\
ME (MJ/day) & $124.2^{\mathrm{ab}}$ & $119.1^{\mathrm{b}}$ & $140.8^{\mathrm{a}}$ & 0.06 \\
Body weight and condition score & & & \\
BW change, g/day & $-102^{\mathrm{a}}$ & $-217^{\mathrm{c}}$ & $-129^{\mathrm{b}}$ & 12.6 \\
Initial BCS & 4.8 & 5.0 & 4.6 & 0.19 \\
Final BCS & 4.3 & 4.5 & 4.6 & 0.17 \\
EFU & 1.0 & 0.9 & 0.9 & 0.19 \\
\hline
\end{tabular}


Table 5 Apparent digestibility coefficient of feed nutrients in cows fed NM stover or NM silage or QPM silage-based diets

\begin{tabular}{lccr}
\hline Digestibility coefficient & \multicolumn{2}{l}{ Treatment } & \\
\cline { 2 - 4 } & NM stover-based diet & NM silage-based diet & QPM silage-based diet \\
\hline DM & 0.70 & 0.75 & 0.74 \\
OM & 0.72 & 0.77 & 0.76 \\
CP & 0.74 & 0.76 & 0.75 \\
NDF & 0.69 & 0.70 & 0.69 \\
\hline
\end{tabular}

$C P$ crude protein, $D M$ dry matter, $O M$ organic matter, $N D F$ neutral detergent fibre, $N M$ normal maize, $Q P M$ quality protein maize, $S E M$ standard error of means

CP content of the NM and QPM silages in the present study was within the range of the minimum level of $7.5 \%$ required for optimum rumen function (Van Soest 1994). However, the CP content of the NM stover below the minimum $\mathrm{CP}$ level required. The low $\mathrm{CP}$ contents of maize varieties in the present study reflected the need for protein supplementation in stover- and silage-based diets. The higher energy content of the NM and QPM silage-based diets might be due to the effect of ensiling, because it increases the energy content of the feeds (De Visser 1993).

Intake and digestibility of nutrients

The higher DMI of the NM stover-based diet than the NM silage-based diet was consistent with the reports that silage DMI was lower than intakes of fresh or dried forages from similar material (Fitzgerald and Murphy 1999). The lower DOMD, DOMI and ME content of the NM stover-based diet than the silage-based diets could be explained, at least in part, by its chemical composition, since NM stover-based diet exhibited very low OM content compared to NM and QPM silage-based diets. The low CP intake by cows fed the
NM stover diet and the higher CP intake by cows fed the $\mathrm{NM}$ and QPM silage-based diets were due to the low CP concentration in the NM stover-based diet and high $\mathrm{CP}$ value of the NM and QPM silage-based diets.

\section{Body weight and condition changes and milk yield and composition}

The relatively high milk fat content of cows on all diets may explain the loss in body weight; however, none of the groups underwent significant body condition change, indicating the cows carried adequate fat stores and that this did not change during the experiment. The loss in body weight of cows could be attributed to suppressed feed intake in the early stages of lactation, high milk yield and milk fat content and nutritional status of cows (Grant et al. 1990).

Although milk yield and milk composition of cows in the present study were not affected by dietary treatments, Sutton et al. (1996) reported an increased milk protein content as a consequence of increased CP concentration in the diet. Depression in milk fat percent is associated with increased supply of glycogenic precursors in the form of
Table 6 Milk yield and constituents of cows fed NM stover, or NM silage or QPM silage-based diets

\begin{tabular}{lcccc}
\hline \multicolumn{2}{c}{ Treatment } & & & SEM \\
\cline { 2 - 3 } & NM stover-based diet & NM silage-based diet & QPM silage-based diet \\
\hline Yield of milk and constituents, kg/day & 10.9 & 11.2 & & \\
Milk yield & 12.2 & 12.7 & 11.2 & 0.38 \\
4\% FCM yield & 0.52 & 0.55 & 12.7 & 0.37 \\
Fat & 0.33 & 0.37 & 0.55 & 0.014 \\
Protein & 0.38 & 0.47 & 0.35 & 0.005 \\
Lactose & & & 0.44 & 0.002 \\
Milk composition, \% & 4.8 & 4.9 & & \\
Fat & 3.1 & 3.3 & 4.9 & 0.03 \\
Protein & 3.5 & 4.2 & 3.2 & 1.41 \\
Lactose & 0.8 & 0.8 & 3.9 & 0.63 \\
Ash & 12.2 & 13.2 & 0.8 & 0.07 \\
Total solids (TS) & 7.4 & 8.3 & 12.8 & 0.21 \\
Solids not fat (SNF) & & & 7.9 & 0.85 \\
\hline
\end{tabular}

$F C M$ fat corrected milk, $N M$ normal maize, $Q P M$ quality protein maize, $S E M$ standard error of means 
propionic acid or starch in the duodenum and decreased supply of lipogenic precursors, namely acetic and butyric acids (Casse et al. 1993).

\section{Conclusions}

The feeding and digestion trials did not reaffirm the assumption that QPM silage-based diet would result in a superior performance in lactating Boran $\mathrm{x}$ Friesian cows than the NM silage-based or NM stover-based diets. The performance among diets was similar as there was no significant difference in milk yield and composition; in fact, body weight loss in the NM stover-based diet was less than the two silage-based diets.

Acknowledgements We thank the International Livestock Research Institute (ILRI), Debre-Zeit Station for providing financial and facility support, and Haramaya University for facilities. Professor Dr. Allan Degen is highly appreciated for reading the manuscript and making valuable comments and suggestions.

Open Access This article is distributed under the terms of the Creative Commons Attribution Noncommercial License which permits any noncommercial use, distribution, and reproduction in any medium, provided the original author(s) and source are credited.

\section{References}

AOAC (Association of Agricultural Chemists), 1980. Official Methods of Analysis, Washington, D.C., USA.

British Standard Institute, 1989. Determination of Fat Content of Milk and Milk Products (Gerber Method) Specification for Apparatus. BS 696-1: 1989. British Standards Publishing Ltd., 24p.

Casse, E.A., Huntington, G.B. and Rulquin, H., 1993. Effect of mesenteric vein infusion of propionate on splanchnic metabolism in first-lactation Holstein heifers. 1. Net uptake or output of fatty acids, ketones and oxygen. J. Dairy Sci., 75:2143-2170.

CIMMYT (International Maize and Wheat Improvement Center), 2000. CIMMYT in 1999-2000. Science and subsistence. Mexico D.F.: CMMYT. ISSN:0188-9214.P. 6-7.

De Visser, H., 1993. Influence of Carbohydrates on Feed Intake, Rumen Fermentation and Milk Performance in High-yielding Dairy Cows. Wageningen, The Netherlands.

Edmonton, A.J., Lean, I.J., Weaver, L.D., Fervor, T. and Webster, G., 1989. A Body condition scoring chart for Holstein dairy cows. J. Dairy Sci., 72:68-78.

Fitzgerald, J.J. and Murphy, J.J. 1999. A Comparison of low starch maize silage and grass silage and the effect of concentrate supplementation of dry forages or inclusion of maize grain with the maize silage on milk production by dairy cows. Prod. Sci. 57: 95-111.

Goering, H.K. and Van Soest, P.J., 1970. Forage fibre analysis (Apparatus, reagents, procedures and some applications). Agricultural Handbook No. 379, USDA. Washington, D.C., USA.

Grant, R.J., Colenbrander, V.F., and Mertens, D.R., 1990. Milk fat depression in dairy cows: Role of silage particle size. J. Dairy Sci. 73:1834-1842.

Kitaba, A. and Tamir, B., 2007. Effect of harvesting stage and nutrient levels on nutritive values of natural pasture in central highlands of Ethiopia. Agricultura Tropica et Subtropica, 40(1), 7-12.

MAFF (Ministry of Agriculture, Fisheries and Food), 1984. Energy Allowances and Feeding Systems for Ruminants. Reference Book 433, HMSO, London, 85p.

Nicholson, M.J. and Butterworth, M.H., 1986. A Guide to condition scoring of Zebu cattle. Addis Ababa, Ethiopia.

NRC (National Research Council), 2001. Nutrient Requirements of Dairy Cattle, 7th revised. National Academic Press, Washington, D.C.

SAS (Statistical Analysis Systems), 2002. SAS/STAT user's guide, SAS Institute Inc., Cary, NC, USA

Scott, R., 1986. Cheese Making Practice, 2nd ed., London/New York, Elsevier Applied Science Publishers, 529P.

Sutton, J.D., Aston, K., Beever, D.E., and Dhanoas, M.S., 1996. Milk production from silage based diets: Effects of high-protein concentrates for lactating heifers and cows on intake, milk production and milk nitrogen fractions. Animal Sci., 62:207-215.

Van Soest, P.J., 1994. Nutritional Ecology of the Ruminant, 2nd ed. Cornell University Press, Ithaca and London, 476p. 